\title{
PENGARUH TEKNOLOGI BLOCKCHAIN TERHADAP KEABSAHAN IJAZAH
}

\author{
Untung Rahardja ${ }^{1)}$, Mulyati ${ }^{2)}$, Frizca Budiarty ${ }^{3)}$ \\ 1,2,3 Universitas Raharja \\ 1'untung@raharja.info, ${ }^{2}$ mulyati@raharja.info, ${ }^{3}$ frizca.budiarty@raharja.info.
}

\begin{abstract}
Abstrak
Ijazah merupakan tanda bukti atau suatu dokumen pengakuan atas selesainya jenjang pendidikan yang telah ditempuh seorang pelajar. Keberadaan Ijazah tentu sangat bernilai penting karena digunakan sebagai alat dalam melakukan berbagai kegiatan diantaranya sebagai dokumen dalam melamar kerja. Pada studi lapangan banyak ditemukan suatu pelanggaran hukum yakni, kasus pemalsuan ijazah untuk tujuan mendapatkan pekerjaan yang layak. Kendati ijazah sangat mudah dipalsukan, hal ini menyebabkan sulitnya memastikan keabsahan dari dokumen tersebut. Hadirnya teknologi blockchain di era 4.0 ini diharapkan mampu dimanfaatkan dalam dunia pendidikan dengan menerapkan keunggulan yang dimiliki oleh blockchain yaitu sistem terdesentralisasi dan kriptografi, maka keberadaan teknologi blockchain akan mampu mengeliminasi keberadaan ijazah palsu dan mampu membuktikan keabsahan ijazah bagi calon pelamar kerja, secara efektif, efisien serta transparan. Penelitian ini mengadopsi 2 metode yaitu, metode analisis deskriptif dan metode studi pustaka. Blockchain diharapkan mampu ikut menyumbang keberhasilan dan meningkatkan kualitas pendidikan nasional.
\end{abstract}

Kata Kunci : Ijazah, Blockchain, Dokumen Palsu, Teknologi

\begin{abstract}
A diploma is a proof or a document acknowledging the completion of the education level a student has taken. The existence of a diploma is of course very important because it is used as a tool in carrying out various activities including as a document in applying for work. In the field study, there were many violations of the law, namely, cases of forgery of certificates for the purpose of getting a decent job. Although diplomas are very easy to falsify, this makes it difficult to ascertain the validity of these documents. The presence of blockchain technology in the 4.0 era is expected to be able to be utilized in the world of education by applying the advantages possessed by blockchain, namely a decentralized and cryptographic system, so the existence of blockchain technology will be able to eliminate the existence of fake diplomas and be able to prove the validity of diplomas for prospective job applicants, effectively, efficiently. and transparent. This research adopted 2 methods, namely, descriptive analysis method and literature study method. Blockchain is expected to be able to contribute to the success and improve the quality of national education.
\end{abstract}

Keywords : Diploma, Blockchain, Fake Documents, Technology

\section{Pendahuluan}

Maraknya kasus pemalsuan dokumen Ijazah yang dilakukan oleh pihak pihak yang tidak bertanggung jawab yang dilakukan dalam rangka meraih suatu tujuan tersendiri yaitu, dalam kegiatan melamar pekerjaan yang lebih layak untuk menaikan taraf ekonomi dalam mencapai kehidupan yang lebih baik ini, mendorong pihak pihak seperti ini untuk melakukan pemalsuan dokumen (Rahardja et al, 2019). Terlebih keberadaan perkembangan teknologi yang semakin revolusioner ini menjadi suatu jalan pintas yang mampu mempermudah jalan bagi para oknum pemalsu Ijazah ini dengan memanfaatkan teknologi dan internet. Kasus ini dapat terjadi karena suatu instansi penerima lowongan kerja kesulitan dalam memastikan keaslian dokumen pelamar kerja dan melakukan verifikasi ijazah yang dikeluarkan oleh perguruan tinggi (Sudaryono et al, 2020). Blockchain pun ikut ambil bagian dalam perkembangan teknologi yang sangat pesat pada era disrupsi ini. Blockchain merupakan teknologi transaksi pencatatan data yang bersifat peer to peer yang akan saling terhubung secara terdesentralisasi yang dimana pada setiap kegiatan berupa transaksi akan diamankan dengan teknik kriptografi yang tersusun oleh 
blok dan transaksi, dimana 2 jenis hal itu kemudian akan disimpan dalam rangkaian rantai blok atau chain yang satu sama lain akan saling berkaitan (Rahardja et al, 2018.

Menurut (Puthal : 2018) Blockchain adalah buku besar yang terstruktur yang di dalamnya terdapat data secara digital, sehingga dapat didistribusikan kepada pihak yang saling terhubung dalam satu jaringan yang bersifat independen (Grech \& Camilleri, 2017). Sedangkan menurut (Vukolić : 2017) Blockchain merupakan sebuah teknologi yang revolusioner yang akan mengubah cara kerja dalam berbisnis. Vukolić juga mengemukakan bahwa blockchain memiliki berbagai jenis diantaranya adalah: 1) Permissioned blockchains : adalah sebuah network yang memungkinkan pengiriman mata uang antara dua pihak dengan rentang waktu yang sangat singkat seperti ripple network (Neisse et al, 2019). 2) Public blockchains: merupakan jaringan besar yang terdistribusi yang dijalankan melalui token dan dapat diakses melalui sebuah kode yang dikelola oleh komunitas yang bersangkutan, 3) Private Blockchain: Blockchain jenis ini memiliki ruang lingkup yang lebih kecil dan tidak menggunakan token.Teknologi blockchain tidak hanya dapat diimplementasikan dalam sektor keuangan saja, tapi dapat dimanfaatkan dalam segala sektor tak terkecuali dalam bidang pendidikan. Perkembangan zaman yang semakin maju ini sebuah pendidikan memiliki nilai yang sangat penting, hal tersebut akan berdampak pada persaingan pada dunia kerja dalam upaya menaikan taraf hidup yang lebih layak (Aini et al, 2020). Sertifikasi adalah syarat utama yang harus dipenuhi seseorang dalam menyelesaikan studi formalnya, tentu saja hal itu pula yang menjadi syarat utama dalam melamar pekerjaan. Kecurangan pemalsuan Ijazah sudah banyak dilakukan dan ditemui, karena ijazah sangat mudah didapat serta dipalsukan keabsahannya. Pemalsuan ijazah merupakan tindakan pidana yang melanggar hukum sebagaimana diatur dalam UUD pasal 263 (KUHP) dengan hukuman penjara selamalamanya enam tahun kurungan penjara. Fokus dari penelitian ini adalah pemanfaatan teknologi blockchain dalam bidang pendidikan (Putra et al, 2019).

\subsection{Tinjauan Pustaka}

\section{Tinjauan Pustaka Dan Landasan Teori}

Studi pustaka adalah sebuah metode penelitian yang dilakukan dalam kegiatan mencari referensi dan informasi dari berbagai sumber seperti, jurnal ilmiah, buku, literatur dan pendapat para ahli yang memiliki kesamaan topik yang diangkat dalam penelitian yang sedang dilakukan. Tujuan dilakukannya studi pustaka adalah untuk mengetahui informasi dari berbagai hasil penelitian yang telah dilakukan sebelumnya, sehingga dapat diusulkan dalam melakukan kegiatan penelitian yang lebih lanjut (Sharples \& Domingue, 2016). Dalam penelitian ini terdapat beberapa studi pustaka mengenai teknologi blockchain dengan penelitian lain yang berkaitan. Berikut 7 (tujuh) studi pustaka yang digunakan dalam penelitian ini diantaranya, yaitu :

Penelitian yang dilakukan oleh Hafizh Fianto Putra, Wirawan Wirawan, Ontoseno Penangsang pada tahun 2019 dalam penelitiannya yang berjudul "Penerapan Blockchain dan Kriptografi untuk Keamanan Data pada Jaringan Smart Grid" pada penelitian yang dilakukannya membahas tentang penggunaan teknologi blockchain dalam keamanan jaringan data smart grid (Febriyanto et al, 2019).

Sedangkan dalam penelitian yang dilakukan oleh Mike Sharples dan John Domingue pada tahun 2016 dengan judul "The Blockchain and Kudos: A Distributed System for Educational Record, Reputation and Reward" pada penelitiannya yang dilakukan oleh mahasiswa The Open University pada Adaptive and Adaptable Learning ini membahas tentang pemanfaatan teknologi blockchain yang terdistribusi dalam kegiatan pencatatan riwayat pendidikan dan daftar prestasi seseorang (Siber, 2019). 
Penelitian yang telah dilakukan oleh Erick Febriyanto, Untung Rahardja, Adam Faturahman, Ninda Lutfian pada tahun 2019 yang berjudul "Sistem Verifikasi Sertifikat Menggunakan Qr code Pada Central Event Information". Penelitian tersebut membahas tentang Qr Code yang digunakan dalam keamanan pemverifikasian sertifikat untuk menghindari terjadinya kegiatan pemalsuan sertifikat, karena sertifikat merupakan hal yang sangat penting karena dijadikan sebagai pembuktian bagi mahasiswa bahwa telah menjalani kegiatan akademik secara formal (Arief \& Sundara, 2017).

Seorang civitas akademika yang bernama saudara Winarno pun telah melakukan penelitian pada tahun 2019 dengan judul "DESAIN E-TRANSKRIP DENGAN TEKNOLOGI BLOCKCHAIN" pada penelitian yang dilakukan oleh winarno ini membahas perihal, penggunaan teknologi blockchain yang diterapkan pada dunia pendidikan dengan memanfaatkan sistem desentralisasi dan kriptografi yang dimiliki oleh blockchain yang akan dapat membantu sebuah instansi pendidikan dalam penyimpanan dokumen berupa sertifikat, ijazah dan transkrip nilai (Ferica et al, 2019).

Mahasiswa STMIK Indonesia Padang yang bernama Lathifah Ariefa pada tahun 2017 telah melakukan penelitian dengan judul "Studi atas Pemanfaatan Blockchain bagi Internet of Things (IoT)". Penelitian yang dilakukannya ini membahas tentang perkembangan yang sangat pesat terhadap ekosistem Internet of Things (IoT) (Sutandi, 2018).

Penelitian yang telah dilakukan oleh Ferica, dkk t tahun 2019 ini berjudul " Analisis Pengaruh Fraud Pentagon Terhadap Kecurangan Laporan Keuangan Menggunakan Beneish Model (Studi Empiris Pada Perusahaan Pertambangan Yang Terdaftar Dalam Bei Periode 2015-2017) “ dalam penelitian ini membahas, analisis fraud pentagon terhadap masalah kecurangan laporan menggunakan beneish model. Yang bertujuan untuk mengetahui pengaruh signifikan terhadap analisa laporan (Underwood, 2016).

Sutandi dalam penelitiannya pada tahun 2018 dengan judul "Pengaruh Big Data Dan Teknologi Blockchain Terhadap Model Bisnis Sektor Logistik Dengan Pendekatan Business Model Canvas" dalam penelitianya membahas tentang strategi persaingan bisnis pada sektor logistik dalam otomasi dan digitalisasi data, yang digunakan organisasi dalam proses pengambilan keputusan. Dengan mengadopsi teknologi blockchain, yang diharapkan akan memberi dampak yang baik dalam pembuatan formulasi kebijakan dengan cepat dan tepat sasaran (Aini et al, 2019).

Dari studi pustaka yang telah dijabarkan diatas, telah menggambarkan beberapa penelitian serupa, terutama mengenai penggunaan dan penerapan teknologi blockchain. Pada penelitian ini lebih terfokus pada bidang edukasi dan pendidikan dengan memanfaatkan teknologi blockchain dalam keamanan ijazah dan pencegahan terjadinya pemalsuan ijazah (Rahardja et al, 2019).

\subsection{Dasar Teknologi Blockchain}

Gambaran sederhana dari blockchain ini adalah sebuah baris data yang mencatat transaksi digital secara terdistribusi yang tergabung kedalam sebuah jaringan yang bersifat independen. Segala transaksi yang tercatat dalam blockchain harus sesuai dengan konsensus jaringan data yang telah disetujui sebelumnya, hal ini tentu saja akan mengeliminasi terjadinya tindakan kecurangan (Liang et al, 2017).

Berikut adalah gambaran sederhana blockchain sebagai sebuah kumpulan atau serangkaian transaksi yang terhubung secara digital atau hash dari block sebelumnya yang akan diilustrasikan pada gambar.1 berikut. 


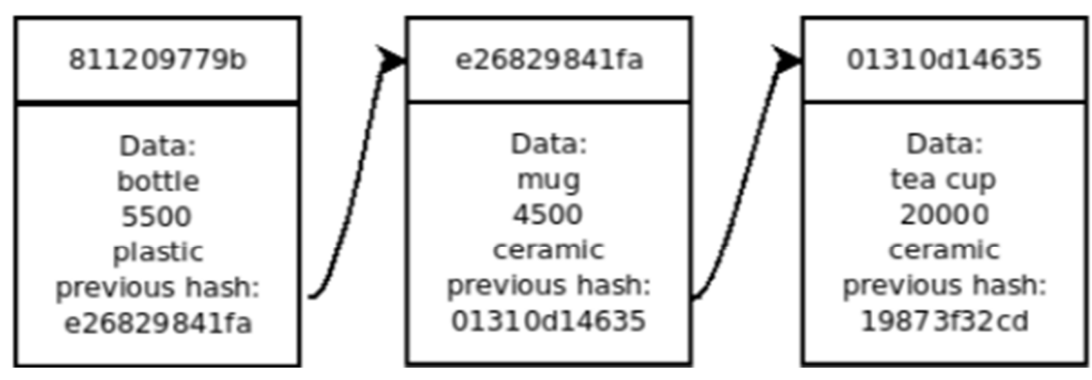

Figure 1. gambaran sederhana Blockchain

Dapat dilihat dari gambar.1 bahwa block yang berada pada blockchain terdiri dari 3(tiga) komponen penting didalamnya, yaitu data, hash sebelumnya dari block terdahulu, dan hash waktu saat block dibuat (Hariguna et al, 2019). Prosedur operasi yang digunakan pada blockchain dalam memastikan keamanan dapat terjaga ada beberapa hal, yaitu:

1. Hash / Tanda Digital.

Hash merupakan hasil dari penggunaan teknik hash dari salah satu teknik kriptografi. Dimana hash tersebut merupakan sebuah algoritma pada pemetaan data acak berbentuk string berukuran tetap yang dirancang sebagai fungsi dalam satu arah yang kemudian fungsi tersebut tidak dapat diubah atau bersifat unik. Yang berarti, dimana baris dari informasi yang telah dibuat tanda digitalnya akan mengalami perubahan, maka yang terjadi selanjutnya adalah hash juga akan mengalami perubahan (Patel, 2019).

2. Peer-to-peer.

adalah sebuah mekanisme yang digunakan dalam kegiatan pendistribusian dari catatan transaksi kepada user yang tergabung pada jaringan blockchain.

3. Proof-of-work

Proof-of-work adalah sebuah mekanisme yang digunakan untuk memperlambat dalam pembuatan block baru yang bertujuan untuk perhitungan pada proses proofof-work pada seluruh block akan terjaga.

\subsection{Permasalahan}

Permasalahan yang ada saat ini adalah mudahnya sebuah ijazah yang dijadikan sebagai dokumen resmi untuk dapat dipalsukan untuk tujuan tertentu yang dilakukan oleh oknum yang tidak bertanggung jawab hal demikian, tentu saja akan merugikan instansi pendidikan terhadap lulusannya. Saat ini proses pengecekan berkas ijazah membutuhkan waktu yang cukup lama sehingga hal tersebut sangat tidak efisien dan efektif serta membutuhkan biaya yang tidak sedikit. Dengan maraknya penyebaran ijazah palsu dan mudahnya memalsukan ijazah hal tersebut akan menimbulkan dan berdampak negatif akan keberlangsungan sumber daya manusia (SDM). maka hal ini tentu tidak sejalan dengan target presiden yang telah ditetapkan dalam gerakan kabinet indonesia maju yang akan menciptakan sumber daya manusia (SDM) yang unggul. Maka, dengan penggunaan manajemen penerbitan dengan teknologi blockchain permasalahan tersebut akan dapat terselesaikan, karena sifat dan ciri khas teknologi blockchain adalah immutable yang artinya tidak dapat diedit dan hanya bisa ditambah. Hal ini tentu saja dapat mengeliminasi pihak pihak yang akan berlaku curang, serta manajemen penerbitan berteknologi blockchain mampu mempercepat aktivitas validasi ijazah (Rahardja et al, 2019). 


\section{Metode penelitian}

Penelitian yang dilakukan kali ini menggunakan metode Ilmiah. Secara sederhana metode ilmiah merupakan sebuah prosedur dan tindakan analitis yang bertujuan untuk mendapatkan pemahaman ilmu pengetahuan ilmiah. Maka dapat diartikan metode penelitian sebagai kaidah atau cara yang sistematis dalam menyusun ilmu pengetahuan. Sedangkan teknik penelitian adalah cara yang dilakukan dalam melaksanakan sebuah metode penelitian (Febriyanto \& Naufal, 2019)..

\section{Hasil Dan Pembahasan}

Sebesar 20\% dari Anggaran Belanja dan Pendapatan Negara (APBN) pada tahun 2019 telah diperuntukan untuk pendidikan sejumlah Rp. 492,5 T. Jumlah itu mengalami kenaikan terhadap RAPBN 2019 sejumlah Rp 4,6 T, dengan jumlah transfer dana ke berbagai daerah sebesar 308,4 $\mathrm{T}$ yang tersebar luas dalam jumlah pusat $163,1 \mathrm{~T}$, dengan jumlah total keseluruhan pembiayaan Rp. $21 \mathrm{~T}$ yang dialokasikan pada bidang pendidikan nasional.

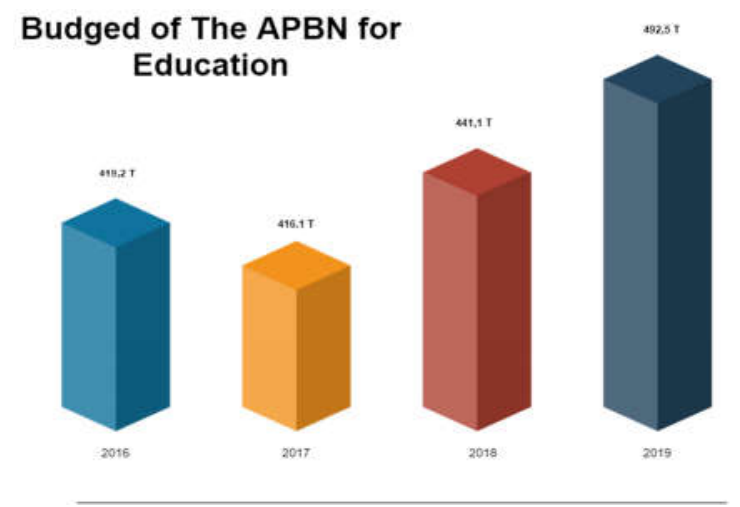

Figure 2. Anggaran Pendidikan dari tahun 2016-2019

Dengan jumlah total keseluruhan yang telah dirincikan, sudah pasti instansi pendidikan akan menerbitkan ijazah sebagai bukti dan keterangan tertulis telah selesainya pendidikan pelajar secara formal. Tentu saja hal ini termasuk sesuatu yang sangat menarik untuk dapat diaplikasikan dengan manajemen penerbitan berteknologi blockchain untuk mengeliminasi terjadinya pelanggaran hukum atas tindakan pemalsuan data berupa ijazah.

Pada proses penerimaan karyawan baru, perusahaan telah banyak mengeluarkan biaya yang cukup besar untuk merekrut tenaga kerja baru, terlebih untuk lulusan fresh graduated yang dimana ijazah sebagai dokumen terlampir pada berkas lamaran pekerjaan harus dilakukannya pemvalidasian keabsahan dari ijazah yang dilampirkan, tentu saja hal ini memerlukan biaya yang relatif tidak sedikit. Pada studi lapangan telah banyak menemukan kasus ijazah palsu yang digunakan untuk kegiatan melamar pekerjaan. Menristek menghimbau kasus pelanggaran hukum pemalsuan ijazah untuk dapat segera diproses dan di usut tuntas karena hal tersebut akan banyak menimbulkan kerugian terutama bagi pihak penerima lowongan pekerjaan, Menristekdikti pun telah menjelaskan bahwa mereka akan berupaya menyelesaikan permasalahan ijazah palsu dalam dunia pendidikan tinggi agar mampu melahirkan ekosistem yang berkualitas serta menciptakan SDM yang unggul (Aini et al, 2020). 


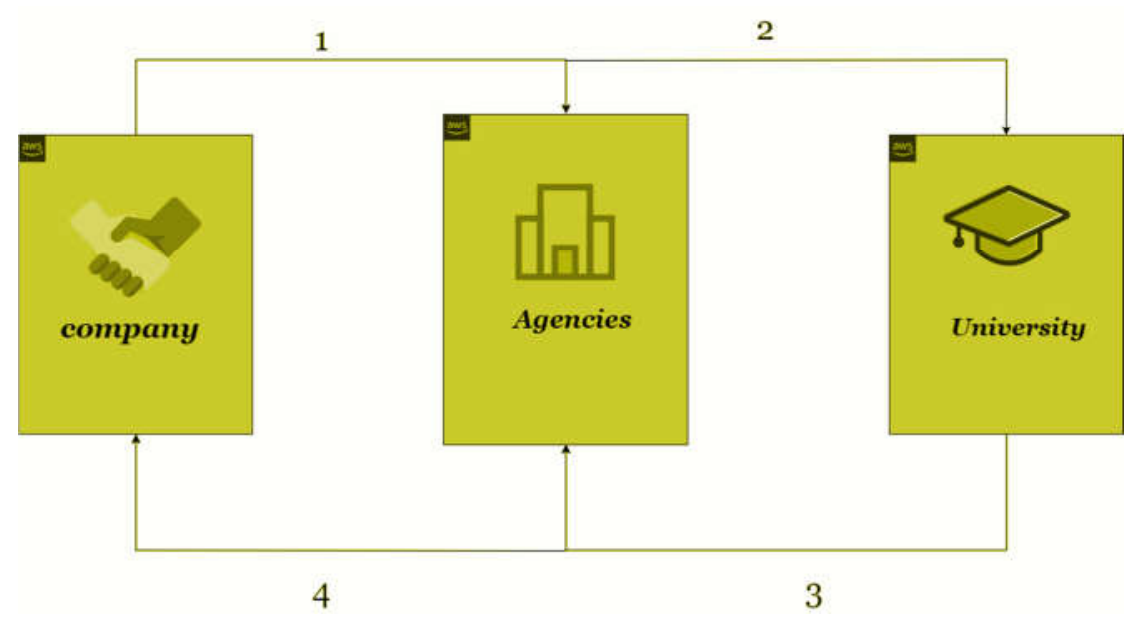

Figure 3. Proses manajemen penerbitan Ijazah.

Pada Figure 3. menggambarkan proses alur dari manajemen penerbitan ijazah secara konvensional pada kegiatan perekrutan tenaga kerja baru. Alur ini menjelaskan proses pelamar kerja baru bagi para fresh graduated pada perusahaan yang akan mereka jadikan tempat untuk melamar pekerjaan. Dimana mereka akan membawa berkas yang akan digunakan sebagai dokumen terlampir yang akan dijadikan sebagai bahan pertimbangan bagi instansi penyedia lowongan pekerjaan. Namun perusahaan tidak dapat memastikan keabsahan dari dokumen ijazah tersebut, sehingga pihak penyelenggara lowongan pekerjaan akan mengirimkan ijazah tersebut kepada pihak instansi terkait yang dapat memastikan keabsahan dari ijazah pelamar kerja, kemudian instansi tersebut akan memastikan keabsahan dari ijazah kepada Instansi Pendidikan terkait yang terlampir untuk memastikan apakah dokumen tersebut benar dan dapat dipertanggung jawabkan (Aini et al, 2020).

Hal ini, sudah dapat dipastikan sangat tidak efisien dan efektif, karena tentunya sangat membuang banyak waktu dan proses seperti ini tentu saja membutuhkan biaya yang tidak sedikit hanya untuk membuktikan keabsahan dari ijazah pelamar pekerjaan. Maka dari itu, proses secara konvensional yang tidak efektif ini harus dikembangkan, agar proses pemvalidasian ijazah akan dilakukan secara efektif, efisien serta transparan tanpa membuang banyak waktu dan biaya yang dikeluarkan relatif lebih murah. Penelitian ini memanfaatkan teknologi blockchain dalam bidang pendidikan atau biasa disebut dengan Blockchain Technology on Education (BTE) untuk memecahkan permasalahan ini (Hariguna et al, 2019).

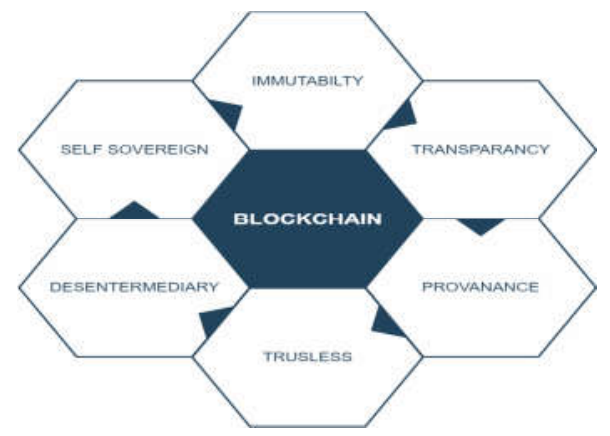

Figure 4. keunikan yang dimiliki blockchain 
Blockchain memastikan dapat memecahkan permasalahan dari tindak kecurangan yang dilakukan oleh pihak yang tidak bertanggung jawab, dalam kegiatan pemalsuan dokumen ijazah. Blockchain memiliki keunikan yang saling berkaitan satu sama lain, dimana hal tersebut tidak dimiliki oleh teknologi lain, keunikan tersebut akan digambarkan dalam Figure 4. Keunikan yang dimiliki oleh blockchain diantaranya adalah Self Sovereignty, Trustles, Transparency, provenance, immutability dan yang terakhir adalah disintermediary. Dimana ke 6 (enam) keunikan yang dimiliki oleh blockchain ini akan dapat menyelesaikan permasalahan, karena blockchain akan mengeliminasi pihak ketiga, dimana hal tersebut akan dapat meminimalisir terjadinya pemalsuan data, karenakan setiap transaksi yang dilakukan terjadi antara kedua belah pihak saja atau disintermediary. Selanjutnya prinsip dari teknologi blockchain sendiri adalah transparan dan immutability, hal ini memiliki artian bahwa setiap transaksi yang terjadi akan bersifat transparan dan setiap data yang masuk dan tersimpan pada blockchain tidak akan dapat diubah, hanya bisa ditambah saja. Jika kita berusaha untuk mengubah data yang sudah tersimpan pada blockchain, hal ini akan mengakibatkan perubahan hash dari block tersebut, Maka hal yang terjadi adalah data akan tidak valid karena hash yang dimasukan tidak sesuai.

Blockchain menerapkan prinsip trustles yang berarti kita tidak perlu percaya kepada siapapun, karena segala aktivitas sudah diserahkan kepada algoritma pemrograman, setiap transaksi akan tercatat di dalam blockchain yang kemudian akan terenkripsi sehingga privasi dan tingkat keamanan pada setiap transaksi sangat tinggi. Pemanfaatan blockchain dalam bidang pendidikan akan memiliki keuntungan yang signifikan, jika blockchain serius diterapkan maka tingkat kecurangan ijazah akan semakin berkurang, karena setiap transaksi yang terjadi pada blockchain akan terhubung dalam sebuah jaringan yang bersifat independen. Blockchain akan membuat segala transaksi tercatat efisien, efektif, aman dan transparan dalam proses kegiatan dalam membuktikan keabsahan ijazah (Lukita et al, 2020).

\section{Kesimpulan}

Untuk dapat mengeliminasi terjadinya dokumen ijazah Aspal (asli tapi palsu), dengan menggunakan metode pengelolaan lain yang masih mengadopsi metode konvensional, yang di dalam pengaplikasiannya masih diterapkannya pihak ke- 3 dalam manajemen pengelolaan sertifikat. Tentu saja, hal tersebut belum dapat menanggulangi keberadaan dokumen Aspal, dikarenakan dalam pendistribusian sertifikat yang berjalan belum didistribusikan langsung kepada pihak penerima, tentu saja hal demikian akan menimbulkan terjadinya peluang peluang kecurangan yang dapat dilakukan oleh pihak yang tidak bertanggung jawab.

Dengan mengadopsi teknologi revolusioner Blockchain dimana segala kegiatan manajemen penerbitan ijazah dilakukan secara digitalisasi serta mengeliminasi keberadaan pihak ke 3 (tiga), tentunya proses pengesahan ijazah akan lebih efektif, efisien dan lebih transparan. Hal ini sudah dapat dipastikan, mampu menekan biaya yang dikeluarkan dalam proses validasi ijazah, jika dibandingkan dengan metode konvensional, Blockchain relatif lebih murah dan dapat meningkatkan efisiensi waktu. Dengan penerapan teknologi Blockchain, ekosistem sumber daya manusia baru akan muncul.

Semua itu bisa terwujud, dengan alasan yang sudah pasti sangat jelas yaitu ijazah sangat sulit untuk dipalsukan dan dimanipulasi isi data dan keasliannya, sehingga eksistensi gelar ijazah aspal akan dapat ditekan keberadaanya. Dampak yang signifikan dihasilkan adalah manfaat ijazah yang diterbitkan oleh pihak berwenang dapat 
dipertanggungjawabkan dan digunakan secara tepat sebagai penilaian uji kompetensi civitas akademika.

\section{Daftar Pustaka}

Aini, Q., Riza, B.S., Santoso, N. P. L, Faturahman, A., \& Rahardja, U. 2020. Digitalization of Smart Student Assessment Quality in Era 4.0," International Journal, vol. 9, no. 1.2.

Aini, Q., Bob R., Santoso, S., Faturahman, A., \& Rahardja, U. (2020). Digitalization of Smart Student Assessment Quality in Era 4.0. International Journal of Advanced Trends in Computer Science and Engineering, 9(1.2), 257-265. https://doi.org/10.30534/ijatcse/2020/3891.22020.

Aini, Q., Badrianto, A., Budiarty, F., Khoirunisa, A., \& Rahardja, U. (2020). "Alleviate Fake Diploma Problem in Education Using BlockChain Technology." Journal of Advanced Research in Dynamical and Control Systems 12(2).

Arief, L., \& Sundara, T. A. 2017. Studi atas Pemanfaatan Blockchain bagi Internet of Things (IoT)," Jurnal RESTI (Rekayasa Sistem dan Teknologi Informasi), vol. 1, no. 1 , pp. 70-75.

Aini, Q., Rahardja, U., \& Hariguna, T. 2019. The Antecedent of Perceived Value to Determine of Student Continuance Intention and Student Participate Adoption of ilearning," Procedia Computer Science, vol. 161, pp. 242-249.

Febriyanto, E., Rahardja, U., Faturahman, A., \& Lutfiani, N. 2019. Sistem Verifikasi Sertifikat Menggunakan Qrcode pada Central Event Information. Techno.Com, vol. 18, no. 1, pp. 50-63, doi: 10.33633/tc.v18i1.2078.

Febriyanto, E., \& Naufal, R. S. (2019). Attitude Competency Assessment in the 2013 Curriculum Based On Elementary School Prototyping Methods. IAIC Transactions on Sustainable Digital Innovation, 1(1), 87-96.

Ferica et al. 2019. Analisis Pengaruh Fraud Pentagon Terhadap Kecurangan Laporan Keuangan Menggunakan Beneish Model (Studi Kasus Empiris Pada Perusahaan Pertambangan Yang Terdaftar Dalam BEI Periode 2015-2017)," Prosiding Seminar Nasional Pakar, vol. 2, no. 8, pp. 1-8, https://trijurnal.lemlit.trisakti.ac.id/pakar/article/view/4239/3365.

Grech, A., \& Camilleri, A.F. 2017. Blockchain in education.” Luxembourg: Publications Office of the European Union.

Hariguna, T., Rahardja, U., \& Aini, Q. 2019. Effect of Social Media Activities to Determinants Public Participate Intention of E-Government," Procedia Computer Science, vol. 161, pp. 233-241.

Hariguna, T., Rahardja, U., Aini, Q., \& Nurfaizah. (2019). Effect of social media activities to determinants public participate intention of e-government. Procedia Computer Science, 161, 233-241. https://doi.org/10.1016/j.procs.2019.11.119

Liang, X., Zhao, J., Shetty, S., Liu, J., \& Li, D. 2017. Integrating blockchain for data sharing and collaboration in mobile healthcare applications," in 2017 IEEE 28th Annual International Symposium on Personal, Indoor, and Mobile Radio Communications (PIMRC), pp. 1-5.

Lukita., Chandra., Hatta, M., Harahap, E.P., \& Rahardja, U. (2020). Crowd Funding Management Platform Based on BlockChain Technology Using Smart Contracts. Journal of Advanced Research in Dynamical and Control Systems 12(2).

Neisse, R., Ramos, J.L.H., Matheu,S.N., Baldini, G., \& Skarmeta, A. 2019. Toward a Blockchain-based Platform to Manage Cybersecurity Certification of IoT devices," in IEEE Conference on Standards for Communications and Networking (CSCN), pp. 1-6.

Patel, V. 2019. A framework for secure and decentralized sharing of medical imaging data via blockchain consensus," Health informatics journal, vol. 25, no. 4, pp. 1398-1411. 
Putra, H.F., Wirawan, W., \& Penangsang, O. 2019. Penerapan Blockchain dan Kriptografi untuk Keamanan Data pada Jaringan Smart Grid," Jurnal Teknik ITS, vol. 8, no. 1, pp. A11-A16.

Rahardja, U., Febriyanto, E., \& Aldiya, M. A. 2019. Penerapan Central Event Information Untuk Mencetak Sertifikat dan Verifikasi Dengan QR Code Menggunakan Global Extreme Programming. Jurnal Informatika Upgris. vol. 4, no. 2, pp. 2-7. doi: $10.26877 /$ jiu.v4i2.2843.

Rahardja, U., Moein, A., \& Lutfiani, N. 2018. Leadership, Competency, Working Motivation and Performance of High Private Education Lecturer with Institution Accreditation B: Area Kopertis IV Banten Province. Man India, vol. 97, no. 24, pp. 179-192.

Rahardja, U., Aini, Q., Graha, Y.I., \& Tangkaw, M.R. 2019. Gamification Framework Design of Management Education and Development in Industrial Revolution 4.0," in Journal of Physics: Conference Series, vol. 1364, no. 1, p. 12035.

Rahardja, U., Harahap, E. P., \& Dewi, S. R. (2019). The strategy of enhancing article citation and H-index on SINTA to improve tertiary reputation. TELKOMNIKA, 17(2), 683-692.

Sudaryono., Rahardja, U., \& Masaeni. 2020. Decision Support System for Ranking of Students in Learning Management System (LMS) Activities using Analytical Hierarchy Process (AHP) Method. Journal of Physics: Conference Series. vol. 1477, no. 2. doi: 10.1088/1742-6596/1477/2/022022.

Sharples, M., \& Domingue, J. 2016. The blockchain and kudos: A distributed system for educational record, reputation and reward," in European conference on technology enhanced learning, pp. 490-496.

Siber, B. 2019. Desain e-Transkrip Dengan Teknologi Blockchain," pp. 1-6.

Sutandi, S. 2018. Pengaruh Big Data Dan Teknologi Blockchain Terhadap Model Bisnis Sektor Logistik Dengan Pendekatan Business Model Canvas. Jurnal Logistik Indonesia, vol. 2, no. 1, pp. 9-20.

Underwood, S. 2016. Blockchain beyond bitcoin.” ACM New York, NY, USA. 